\title{
THE APPLICATION OF THE POLYA'S STEPS REVIEWED FROM PROBLEM-SOLVING ABILITY IN TWO-VARIABLE LINEAR EQUATION SYSTEM (SPLDV)
}

\author{
Nana Sepriyanti ${ }^{1}$, Zulvia Trinova ${ }^{2 *}$, Andi Susanto ${ }^{3}$, dan Ridhatul Mahmuda ${ }^{4}$ \\ Faculty of Tarbiyah and Teacher Training, Universitas Islam Negeri Imam Bonjol \\ *Email: zulvia.trinova12@gmail.com \\ Website: http://jurnal.uin-antasari.ac.id/index.php/itjik \\ Received: 28 March 2020; Accepted: 10 June 2020; Published: 30 June 2020
}

\begin{abstract}
The ability of students in this school is low in understanding the questions given by the teacher. As a result they find it difficult to know the steps on how to solve the problem. Efforts that can be done are implementing Polya's steps.Quasi-experimental research was conducted in this study with the Randomized Control Group Only Design. Students of class VIII at this school are used as population. The experimental class is class VIIIA and the control class is class VIIIB. Final test data in the form of essays obtained were analyzed by $t$ test. The result is the average problem solving ability with the application of Polya's steps, 78.23 and the control class, 72.38 , with achievement in the experimental class $81 \%$ and in the control class, $48 \%$. After being analyzed, $t$ _count $=2.33$ and $t$ table $=1.68$ with a confidence level of $95 \%$ so that $t$ _count $>t$ table (2.33> 1.68), meaning that the proposed hypothesis is accepted and the ability of students in solving problems using Polya steps is higher rather than without applying these steps.
\end{abstract}

Keywords: polya step; problem solving; two variables linear equation

\section{INTRODUCTION}

Mathematics as science is related to thinking patterns and logic processing (Suherman, 2003; Amir, 2014; Rachmayani, 2014). The purpose of learning in Mathematics is that students can solve problems, in the form of understanding a problem, creating a model, and interpreting a solution. They are expected to solve the problem after learning Mathematics (Hurme \& Jarvela, 2005; Lee \& Hollebrands, 2006). Learning Mathematics can provide training and develop their abilities. The question (soal cerita) is related to mathematical concepts, and they must know what steps are taken first. For that in solving mathematical problems needed tactics or strategies in solving it. So the authors are interested in researching the right steps to solve a mathematical problem which is by applying Polya's steps.

Polya is a professor of Mathematics in the fields of combination, numbers, numerical analysis, and probability theory. His full name is George Polya. (D'Agostino, 2011; Kilpatrick, 2011; Hensberry \& Jacobbe, 2012) Poly has a much-needed step because it has procedures in solving mathematical problems (Chen \& Cuba, 2013; Caron, Davy, \& Daucet, 2012; Marlina, 2013; Tarigan, 2012). Polya stipulates there are 4 steps so that students can solve mathematical problems, understanding the proposed problems, planning how to solve, solving them, and checking answers.

The application of Polya's steps is expected to help them solve problems in Mathematics and believe in the results they will get a higher score than without applying these steps.

Research in SMP Negeri 3 Bayang applies the material system of two-variable linear equations (SPLDV). The hypothesis is that participants can solve higher problems by applying Polya's steps than 
without applying Polya's steps in solving problems.

\section{RESEARCH METHODS}

This type of research is quasiexperimental research. The study used an experimental class and a control class. Reiser \& Simmon, 2005; Hui, Lam, \& Law, 2000; Suryabrata, 2014; stated that quasiexperimental research to obtain the results of experiments conducted. Students are grouped into experimental and control groups. The experimental class applied Polya's steps in the form of story problems, while the control class did not apply Polya's steps. The study was designed using "The Static Comparation: Randomized Control Group Only Design".

Table 1. Research Design

\begin{tabular}{|l|c|c|}
\hline \multicolumn{1}{|c|}{ Group } & Treatment & Posttest \\
\hline Experiment & $\mathrm{X}$ & $\mathrm{T}$ \\
\hline Control & - & $\mathrm{T}$ \\
\hline
\end{tabular}

Source: Suryabrata (2004, p 104)

Note:

$\mathrm{X}=$ Treatment in the experimental class, by applying Polya's steps in solving story problems

$\mathrm{T}=$ Test for the experimental and control class

Research at SMP Negeri 3 Bayang was carried out in class VIII. All students of class VIII in this school were made into a population and the sample was representative of the population studied. The technique used is total sampling, the sample is chosen randomly by lottery. For the experimental class VIII(A) is selected and the control class VIII(B) is chosen.

The independent variable in this study is learning with Polya steps while the dependent variable is the ability of students in problem-solving.

The type of primary data in this study is about students 'problem-solving abilities by applying Polya's steps and students' problem-solving abilities by applying ordinary learning without using
Polya's steps. Furthermore, secondary data is obtained from the daily test scores of students.

The instrument was taken from 5 essay test questions. Trial tests are carried out starting from the analysis of validity, to the level of difficulty items. Data on student learning outcomes are collected through the last meeting essay test. The next step is the answer sheet is collected and checked. The study consisted of three stages: the preparation, implementation, and final stages.

The data analysis technique was performed by t-test, to find out the results of students' problem-solving abilities in the experimental class that were very different from the control class. The t-test formula formulated by Sudjana (2005: 466) is as follows:

With:

$$
\mathrm{t}=\frac{\overline{X_{1}}-\overline{X_{2}}}{S \sqrt{\frac{1}{n_{1}}+\frac{1}{n_{2}}}}
$$

$$
S=\sqrt{\frac{\left(n_{1}-1\right) S_{1}^{2}+\left(n_{2}-1\right) S_{2}^{2}}{n_{1}+n_{2}-2}}
$$

Ket:

Note:

$X_{1}=$ the average score of the experimental class

$X_{2}=$ control class average score

$n_{1}=$ number of experimental class students

$n_{2}=$ number of control class students

$S_{1}{ }^{2}=$ standard deviation of the experimental class

$S_{1}{ }^{2}=$ standard deviation of the control class

The t-test fulfilled two conditions, samples from normal populations and homogeneous variances. This test is conducted to determine the ability of students in solving problems by applying Polya's steps is higher than without applying these steps in problem-solving.

\section{FINDING AND DISCUSSION}

\section{A. Research Finding}

The author's data is obtained from the implementation of the second class test. 
The test consists of 5 (five) items of description questions. The test was followed by 21 students in the experimental class and 21 people in the control class.
From the analysis conducted, the interpretation obtained in Table 2.

Table 2. Student's Problem Solve Ability

\begin{tabular}{|l|c|c|c|}
\hline \multirow{2}{*}{ No } & \multirow{2}{*}{ Interval } & \multicolumn{2}{|c|}{ Frequency } \\
\cline { 3 - 4 } & & Experiment & Control \\
\hline 1. & $60-65$ & 3 & 5 \\
\hline 2. & $66-71$ & 1 & 6 \\
\hline 3. & $72-77$ & 4 & 6 \\
\hline 4. & $78-83$ & 9 & 1 \\
\hline 5. & $84-89$ & 2 & 2 \\
\hline 6. & $\geq 90$ & 2 & 1 \\
\hline & $\mathrm{N}$ & 21 & 21 \\
\hline & Max & 90 & 60 \\
\hline & Min & 64 & Pass $(48 \%)$ \\
\hline & Percentage & Pass (81\%) & No Pass $(52 \%)$ \\
\cline { 2 - 4 } & & No Pass (19\%) & 72,38 \\
\hline & $\bar{x}$ & 78,23 & 89,2224 \\
\hline & $S^{2}$ & 56,8516 & 8,32 \\
\hline & $S$ & 7,54 & \\
\hline
\end{tabular}

Note:

$N=$ The number of students

$x=$ Average student mastery in general

Maximum Score $=$ The highest score

Minimum Score $=$ The lowest score

$S^{2}=$ Variance

$S=$ Standard Deviation

The table illustrates that the average mathematical value in the experimental class is 78.23 which has a higher value than the control class that is 72.38 . The variation of the experimental class is 56.8516 and the control class 69.2224. The standard deviation of the experimental class is 7.54 and the control class is 8.32 . The maximum value is 90 and the control class is also 90 . Whereas the minimum values are 64 and
60. This illustrates that the experimental class obtained the ability of students to solve higher problems.

Based on the KKM (the lowest score) set by this school that is 75 , from the results of tests of students' mathematical problem-solving abilities in the experimental class it is known that the value of students who reached KKM was 17 students while in the control class were 10 students.

Data about students' mathematical problem solving abilities is obtained through mathematics problem solving ability tests. The problem solving ability test data consists of five questions that contain the following four indicators:

Table 3. Achievement of Problem Solving Capability Indicators

\begin{tabular}{|c|l|c|c|}
\hline \multirow{2}{*}{ No } & \multicolumn{2}{|c|}{ Indicator } & \multicolumn{2}{c|}{ Class } \\
\cline { 3 - 4 } & & Experiment & Control \\
\hline 1. & Understanding of problem & $91,61 \%$ & $86,47 \%$ \\
\hline 2. & Planning to solve the problem & $86,85 \%$ & $79,80 \%$ \\
\hline 3. & Solving the problem & $77,90 \%$ & $73,90 \%$ \\
\hline 4. & Review Average & $56,57 \%$ & $49,33 \%$ \\
\hline \multicolumn{2}{|c|}{} & $78,23 \%$ & $72,38 \%$ \\
\hline
\end{tabular}


This table explains the indicators of different student abilities. The first indicator obtained the value of the experimental class $91.61 \%$ and $86.47 \%$ control class. The second indicator obtained the value of experimental class 86.85 and 79.80 control class. The third indicator obtained was 77.90 experimental class and 73.90 control class and the fourth indicator obtained the experimental class value of 56.57 and 49.33 control class.

From the normality test obtained, it was concluded that both sample classes were normally distributed. $L_{\text {tabel }}$ for each sample class is greater than $L_{0}$, for the problem solving ability of experimental students and control classes are respectively obtained $L_{0}=0.07$ and $L_{0}=0.13$; while $L_{\text {tabel }}=0.19$ and $L_{\text {tabel }}=0.19$. Homogeneity test is done with the F test, from the calculations, obtained

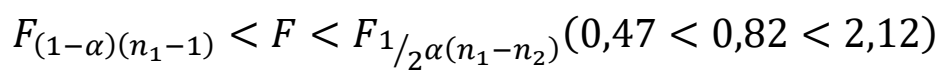

So it can be concluded that the two sample classes have homogeneous variance.

From the Kolmogorof-Smirnov normality test and homogeneity test with the $\mathrm{F}$ variance test, it is obtained that both samples have homogeneous variances. The testing criteria used are: $t_{\text {hitung }}>t_{\text {tabel }}$, the students' problem-solving skills are better.

The results obtained about the ability of students are obtained respectively $t_{\text {hitung }}=2.33$ and $t_{\text {tabel }}=1.68$; Based on the results obtained, it appears that $t_{\text {hitung }}>t_{\text {tabel }}$. This shows that the problem-solving ability of students by applying Polya steps is higher than without applying these steps.

\section{B. Discussion}

This research was conducted during 4 meetings, that are face to face and 1 test which amounted to five items of essays. Time allocation is $2 \times 40$ minutes. The implementation of learning at each meeting consists of preliminary activities, core activities, and closing activities. Implementation of learning every time the meeting starts with a greeting, pray, then check the presence of students and then proceed with discussing homework (PR) provided. This is done so students can find out their mistakes in doing homework so that they are more understanding in solving the next questions.

The core activity of each meeting in the experimental class is by implementing Polya's steps: knowing the problem, making a plan, solving the problem, and checking the final results. At the core activity, the educator gives an example of solving a story problem with Polya's steps. then proceed with the distribution of LKPD to students that contain Polya steps. In this activity, the stage of guiding students is carried out. Educators convey how to complete the LKPD field. When LKPD is done, activities are observed and control the workings of students. After completing the LKPD, some representatives were asked to make answers on the board and discussed together the correctness of the resolution of the questions that were solved.

The first meeting in the experimental class educators introduced Polya's steps to the next meeting in solving the questions. Learning at this meeting was not appropriate because of Polya's step so that many students asked about Polya's steps so that the material at this meeting was only an introduction to the system of linear equations.

In the second meeting, students have begun to know the procedure to solve the problem using Polya steps. At this meeting, the material discussed was the completion of SPLDV story questions using graphical 
methods and elimination methods. When working on LKPD, many students complained that the solution to the problem was very long and complicated. Under these circumstances, educators try to guide students to complete the answers in the LKPD. One of the questions in LKPD is:
"2 cars and 3 robots purchased by Risky for Rp. 53,000.00, and Rifky purchased 5 cars and 2 robots for Rp. 83,000.00. How much is the price of 1 car and 1 robot ".

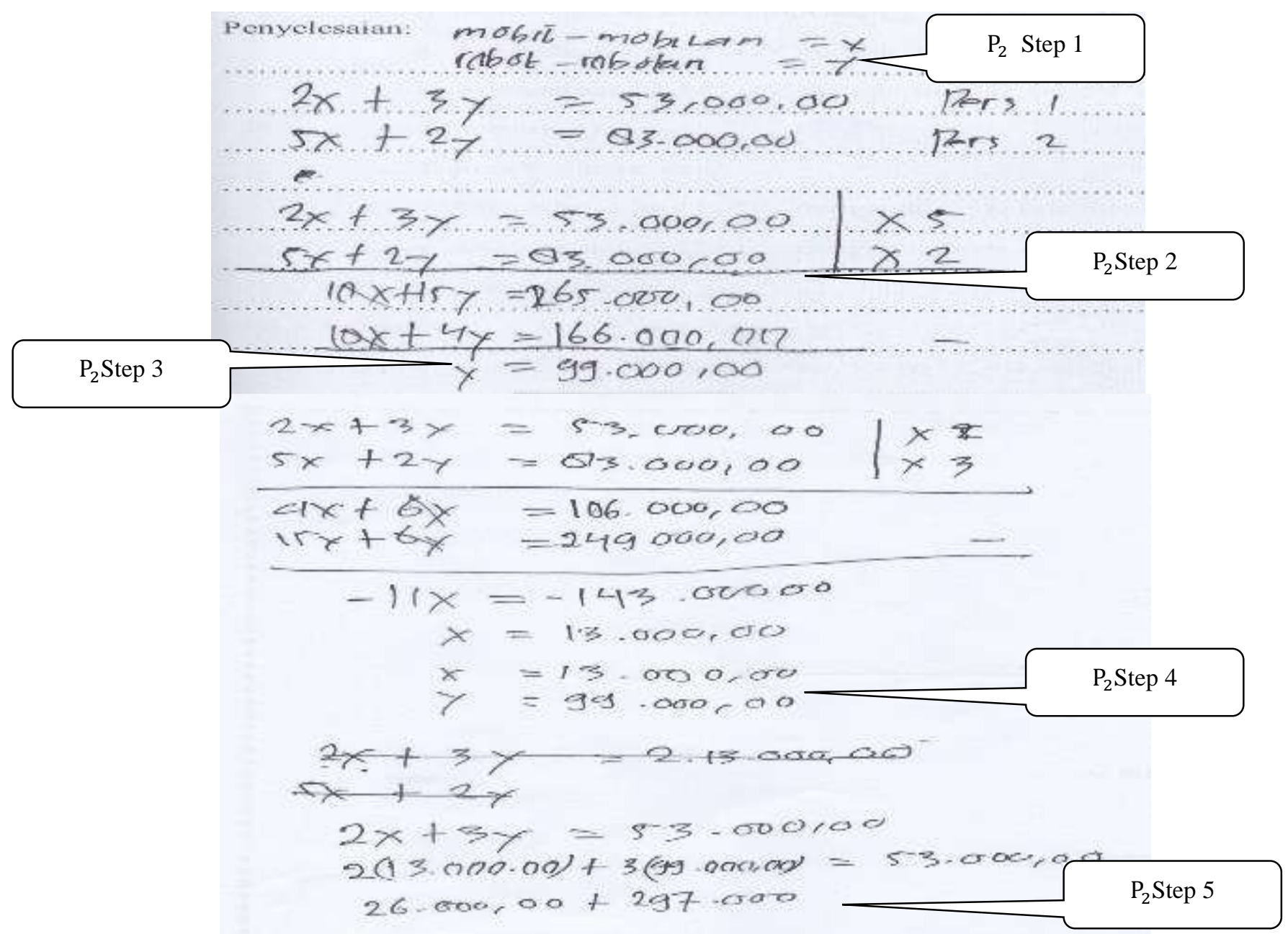

Picture 1. Student's Answer of LKPD on Second Meeting

In completing the problem RW leaves the first step of Polya's step, which is about understanding the problem and he goes directly to the second step, which is planning a solution by making an example $\left(\left(\mathrm{P}_{2}\right.\right.$ step 1$)$, then RW directly goes to the third stage, which is solving the problem $\left(\left(\mathrm{P}_{2}\right.\right.$ step 2$)$, in completing this third stage RW experiences errors in the subtraction stage, RW subtracts $5 y$ from $4 y$. RW should subtract $15 \mathrm{y}$ to $4 \mathrm{y}$. The condition makes the variable was incorrect, RW gets a value of $\mathrm{y}=99,000.00$ should $\mathrm{y}=$ $9,000.00$ then WD continues searching for the value of variable $\mathrm{x}$. RW gets the value $\mathrm{x}$ $=13,000.00\left(\left(\mathrm{P}_{2}\right.\right.$ step 4$)$ so, $\mathrm{RW}$ gets the solution of the problem with the price of cars $(\mathrm{x})=13,000.00$ and robots $(\mathrm{y})=$ $99,000.00$. the solution should have been the price of cars $(\mathrm{x})=13,000.00$ and robots $(y)=9,000.00$ with the condition that the fourth step of Polya RW was also mistaken about checking again $\left(\left(\mathrm{P}_{2}\right.\right.$ step 5$)$. 
In the third meeting entered into the SPLDV settlement material with the substitution method and the mixed method (a combination of substitution and elimination methods) with the application of the Polya step. At the core activity, the educator starts learning with questions at LKPD, after the educator is finished giving examples of questions and they understand the questions and are told to work on the existing problems. One of the questions in the LKPD is "A magazine trader managed to sell magazine A and magazine B for 28 copies. The price of one copy magazine $\mathrm{A}$ is Rp. 6,000.00 and the price of one copy magazine B is Rp. 9,000. If the sales of the two magazines are Rp. 216,000.00. Then determine the number of magazines $\mathrm{A}$ and magazine $\mathrm{B}$ are sold "!

In seeing students 'problems, they can write what data is known and what is asked $\left(\mathrm{P}_{3}\right.$ step 1), but in the step of making students' planning, they only make mathematical models of students not to make an example $\left(\mathrm{P}_{3}\right.$ step 2$)$. Furthermore, in the step of solving the problem, the students mistakenly operate when substituting should be reduced $\left(\mathrm{P}_{3}\right.$ step 3$)$. So that the checking step again is wrong $\left(\mathrm{P}_{3}\right.$ step 4), and they do not conclude the answer. The following answers MG students:

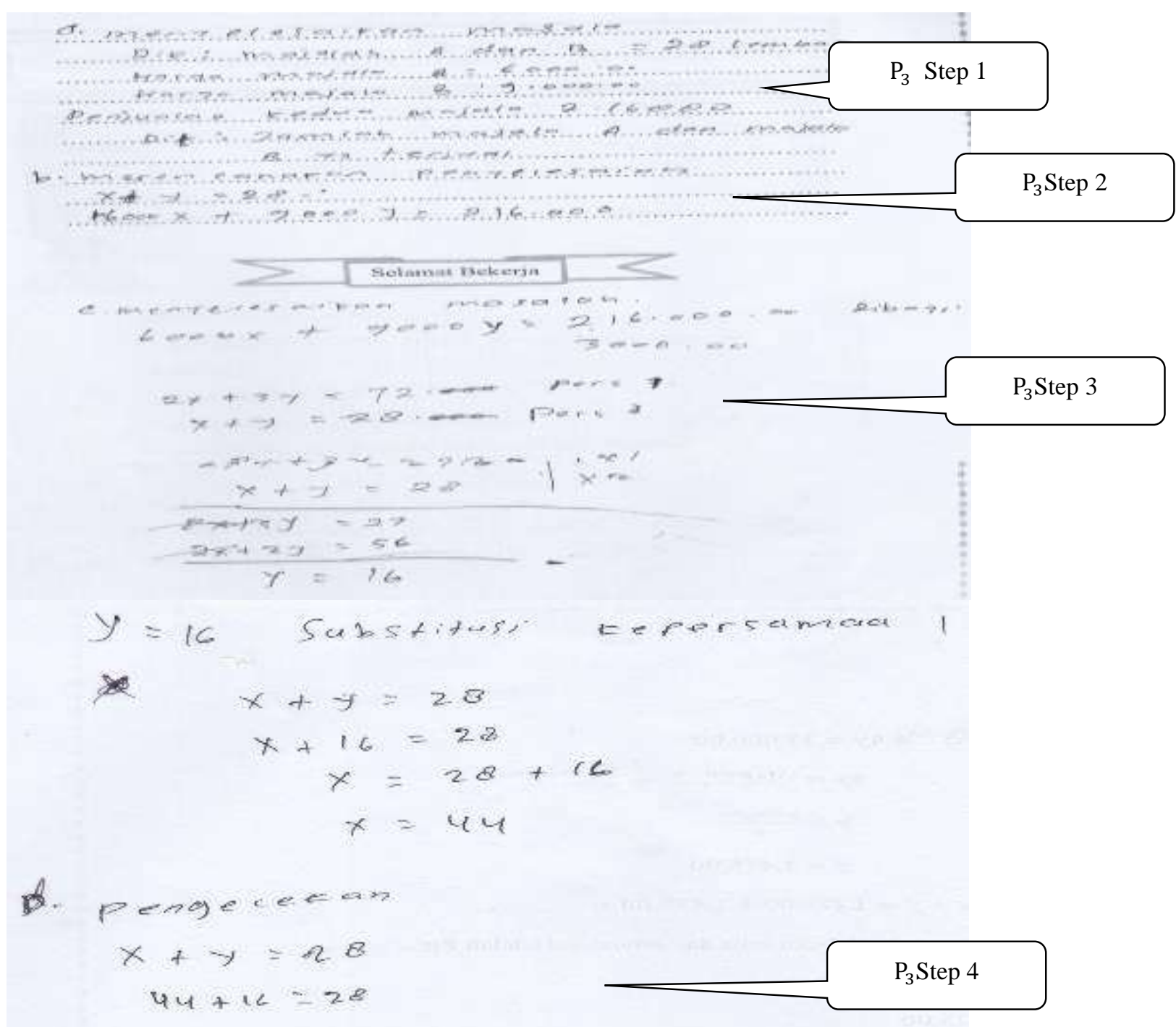

Picture 2. Student's Answer of LKPD on Third Meeting 
At the fourth meeting, the students entered into the settlement of various forms of SPLDV questions using graphical, elimination, and substitution methods. One of the questions discussed at this meeting is:
"Andre has money that if 3 times of the money owned by Budi Rp. 64,500 is added and 2 times the money owned by Andre plus 4 times the money owned by Budi in the amount of Rp. 100,000. How much is Andre and Budi's money?"

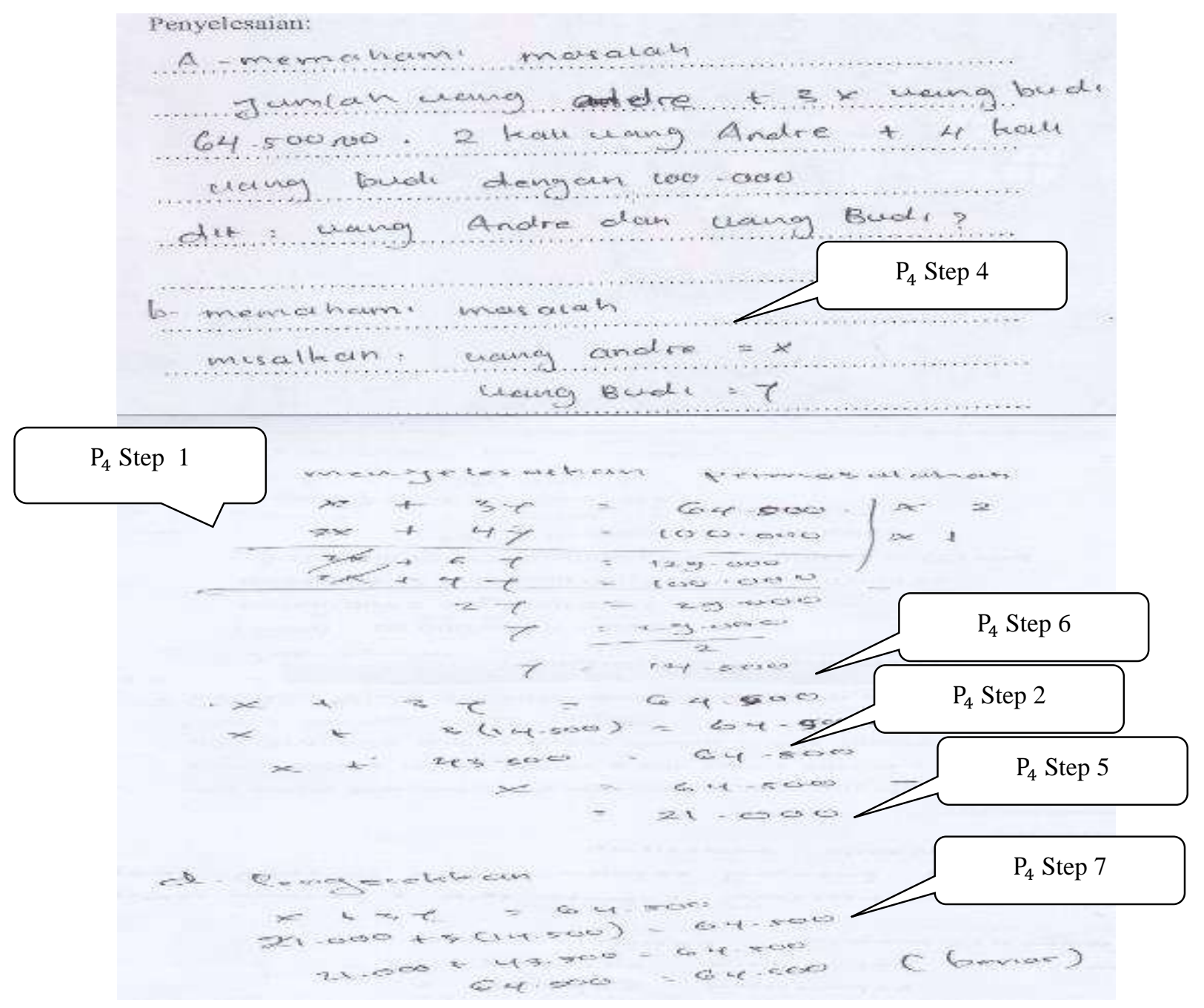

Picture 3. Student's Answer of LKPD on Fourth Meeting

Students are able to solve the questions at LKPD meeting 4. Students in this problem choose a solution using a combination of elimination methods ( $\mathrm{P}_{4}$ step 1$)$, substitution $\left(\mathrm{P}_{4}\right.$ step 2$)$, students can already write down what known and asked ( $\mathrm{P}_{4}$ step 3$)$. However, in the stages of planning the completion of the students only assume and does not make a mathematical equation model $\left(\mathrm{P}_{4}\right.$ step 4$)$. Learners do not make conclusions from the answers obtained. But the results obtained by $\mathrm{SB}$ are correct with the variable $\mathrm{x}=$ $21,000\left(\mathrm{P}_{4}\right.$ step 5) and the variable $\mathrm{y}=$ $14,500\left(\mathrm{P}_{4}\right.$ step 6$)$, the students have also checked correctly $\left(\mathrm{P}_{4}\right.$ step 7$)$.

As for the control class, the core activity begins with the educator explaining how to solve SPLDV questions with existing methods (graphical method, elimination, and substitution) sign mentioning the steps of solving the problem. After students explain the 
material, students work on LKPD with the usual steps taken in answering questions about the story by making known (diketahui), asked (ditanya) and answered (dijawab) without stressing the students must double-check the results that have been obtained. Closing activity every time the meeting in the experimental class and the control class, the educator asks students to jointly conclude the learning on that day and remind them again to repeat today's lesson at home and remind them not to forget to make homework.

After completing four face-to-face meetings, the next meeting was given a final test to see the understanding of the material being taught. The test was given to the two classes, the experimental and control class consisting of 5 items each class. The following will explain the questions and answers of students from the final test given, namely:

The first question "Budi and Ahmad are brothers. Budi has 7 marbles more than Ahmad marbles. Ahmad Marbles as many as 20 pieces. How many marbles does Budi have?"

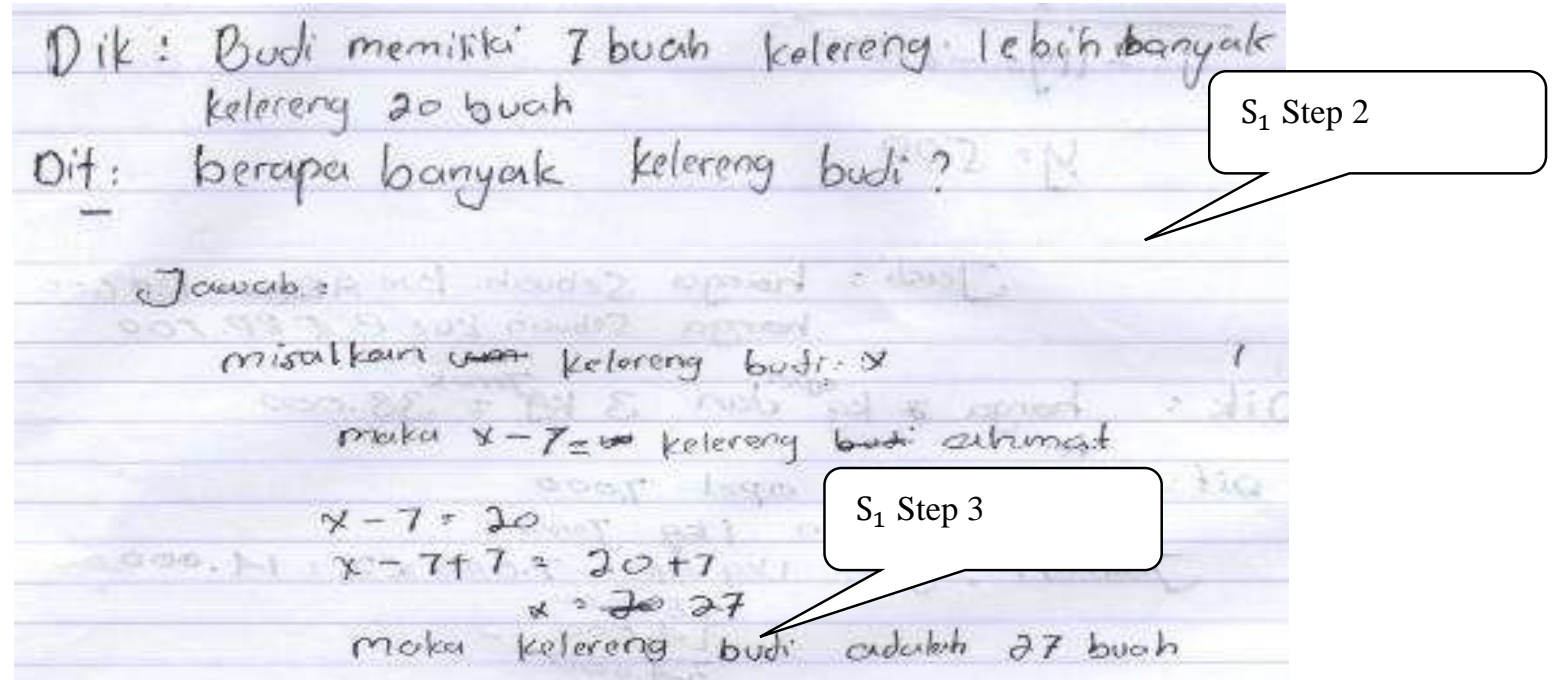

Picture 4. Student's Answer of Posttest Question 1

The solution to problem 1 can be seen from MN. MN in solving problem 1 he immediately made known, asked in the problem $\left(\left(S_{1}\right.\right.$ step 1$\left.)\right)$ then immediately solved the problem by making an example $\left(\left(\mathrm{S}_{1}\right.\right.$ step 2$\left.)\right)$. Although the results obtained by $\mathrm{MN}$ were correct, namely 27 $\left(\left(\mathrm{S}_{1}\right.\right.$ step 3$\left.)\right)$, but he did not take Polya's steps in solving the problem and he also did not check the results he got back. When interviewed with $\mathrm{MN}$, the results obtained why he did not make the settlement according to Polya's steps, which he said were very long and to save time, he immediately answered like Figure 5.

The second question "Two $\mathrm{kg}$ of apples and three $\mathrm{kg}$ of oranges is valued at Rp. 38,000.00. If one $\mathrm{kg}$ of apples is $\mathrm{Rp}$. $7,000.00$. How much is $1 \mathrm{~kg}$ of orange? " Problem-solving can be seen from students in picture 4.5 


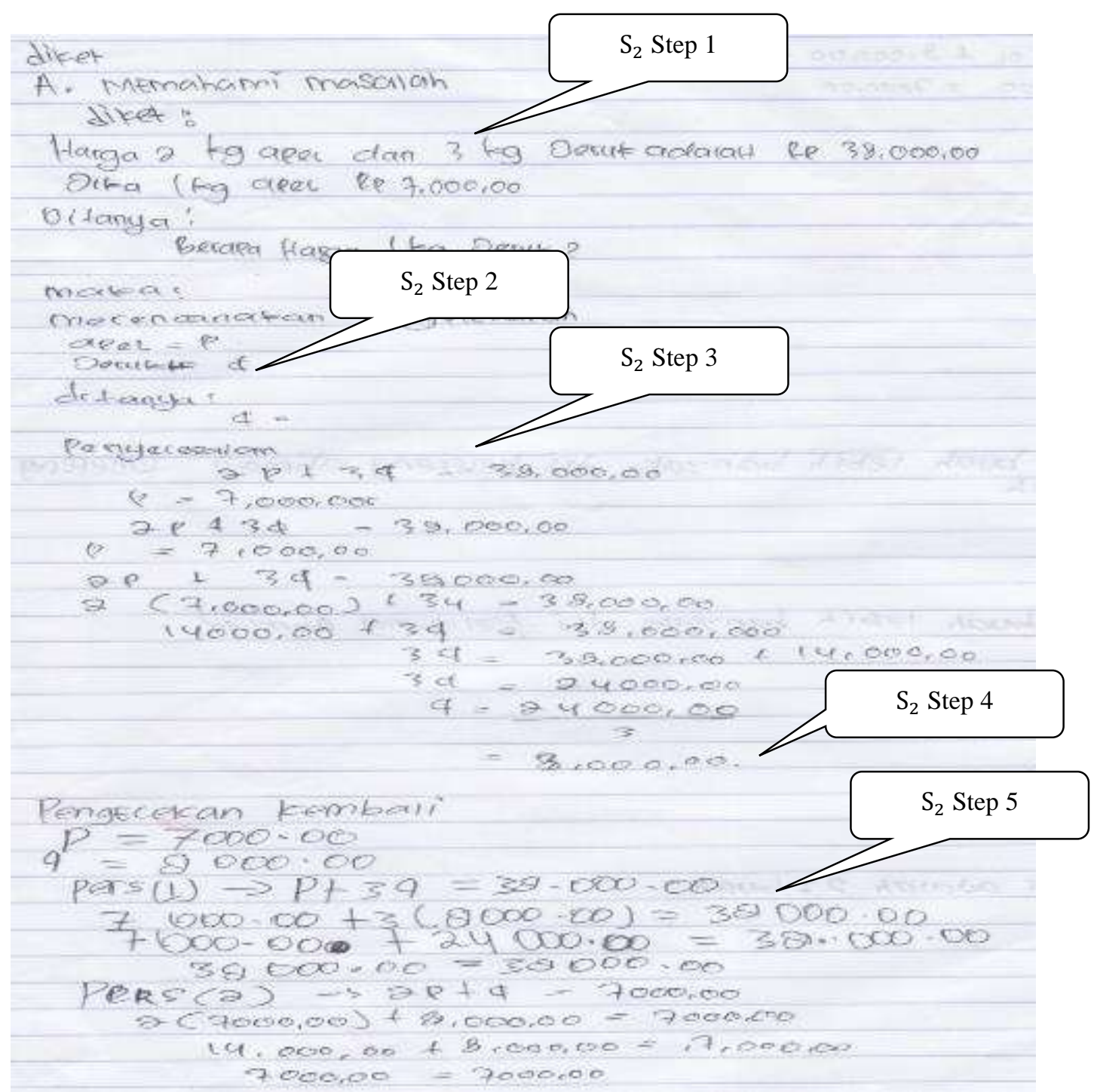

Picture 5. Student's Answer of Posttest Question 2

SU has already made known and asked completely ( $S_{2}$ step 1$)$, but in the step of planning the completion of SU, it only makes an example without making a mathematical model $\left(S_{2}\right.$ step 2$)$, even though in the third stage, solving the SU problem makes the mathematical model correctly $\left(S_{2}\right.$ step 3$)$, and get the right results $\left(S_{2}\right.$ step 4$)$, Then $S U$ has also checked the results that it can get correctly and correctly too $\left(S_{2}\right.$ step 5$)$, But there is still a lack of SU answers, he does not make conclusions from the results obtained. When the interview was conducted, SU answered that he forgot to make that conclusion.

The third question " 2 cakes $\mathrm{A}$ and 5 cakes B for theprice of Rp 4,000; 3 cakes $\mathrm{A}$ and the price of 2 cakes $\mathrm{B}$ worth $\mathrm{Rp}$ $2,700.00$. The price of 1 cake $A$ and 2 cakes $\mathrm{B}$ is ..." 


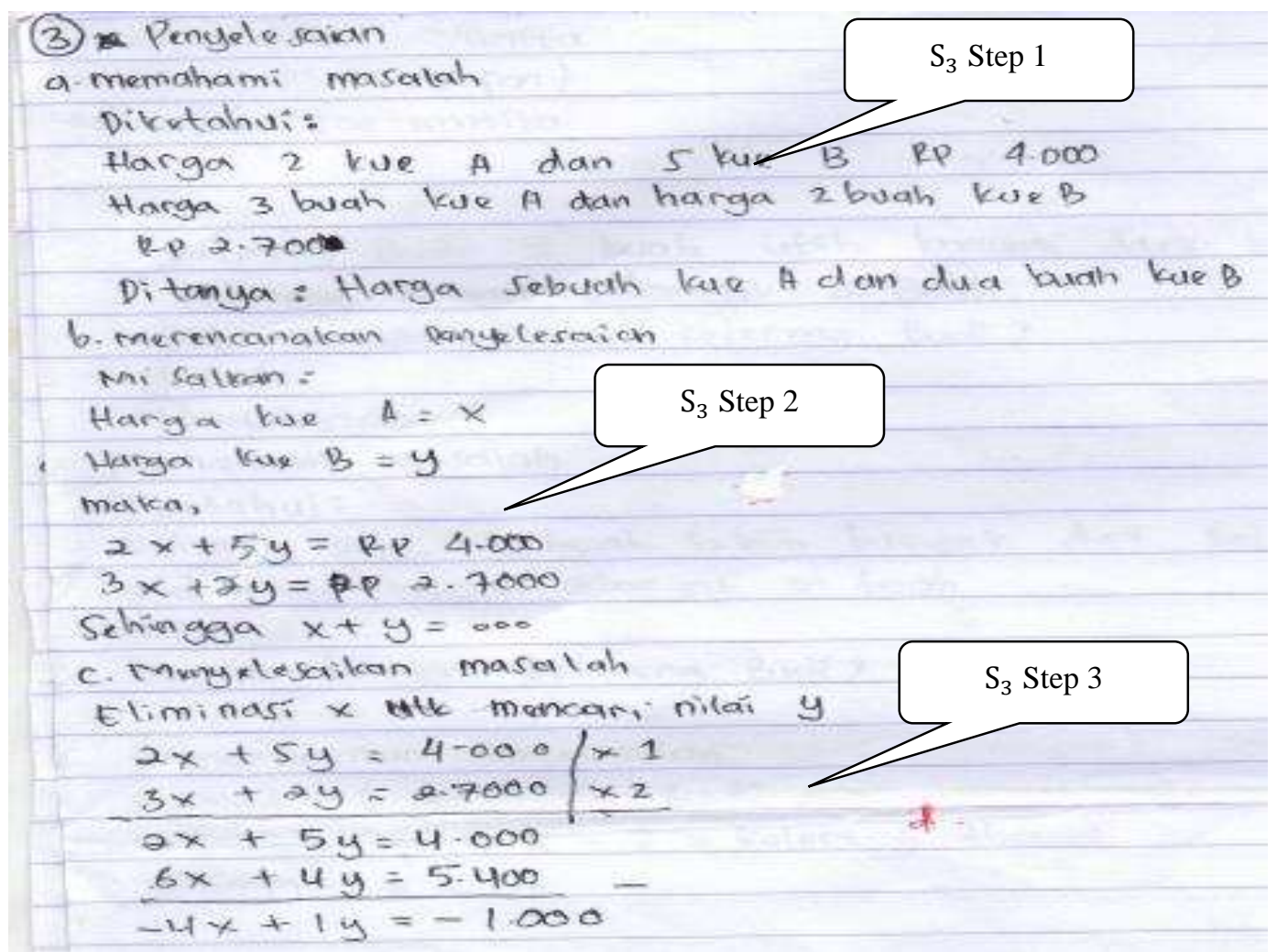

Picture 6. Student's Answer of Posttest Question 3

In solving the problem, PY only makes 3 Polya steps in the first step, PY has made the understanding problem correctly $\left(\mathrm{S}_{3}\right.$ step 1$)$, planning the settlement also correctly $\left(\mathrm{S}_{3}\right.$ step 2$)$, but in the third step of Polya, solving the problem, PY only made half the way wrong in equating one of the variables $\left(S_{3}\right.$ step 3$)$. When interviewed about the problem he wrote the answer, PY answered because in the third step he forgot how to eliminate must be multiplied by how many so that one of the variables could be lost.

Question four, "Mr. Sandi has a rectangular land. The land has a circumference of 28 $\mathrm{cm}$, if the width is more or less $2 \mathrm{~cm}$ from its length, then how large is Mr. Sandi's land? "
In this problem, students only make 2 steps, namely the first step and the second step Polya. The first step is understanding the problem $\left(\mathrm{S}_{4}\right.$ step 1$)$ and the second step is planning for completion $\left(\mathrm{S}_{4}\right.$ step 2$)$. To reveal the reasons why these students only make two steps. Educators interview students and get answers to the reasons he solved the problem with 2 steps. The students' answers were because time was about to run out and he wanted to solve problem number 5 so he left question number 4 first, if there was time then he continued to answer question number 4 . But before he finished solving problem number 5, time was up, so he didn't have time to continue solving problem number 4 .

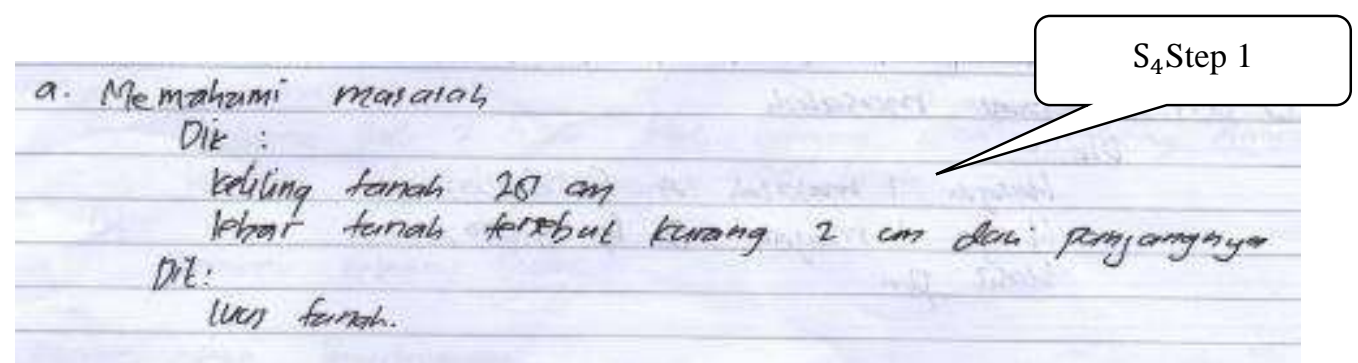




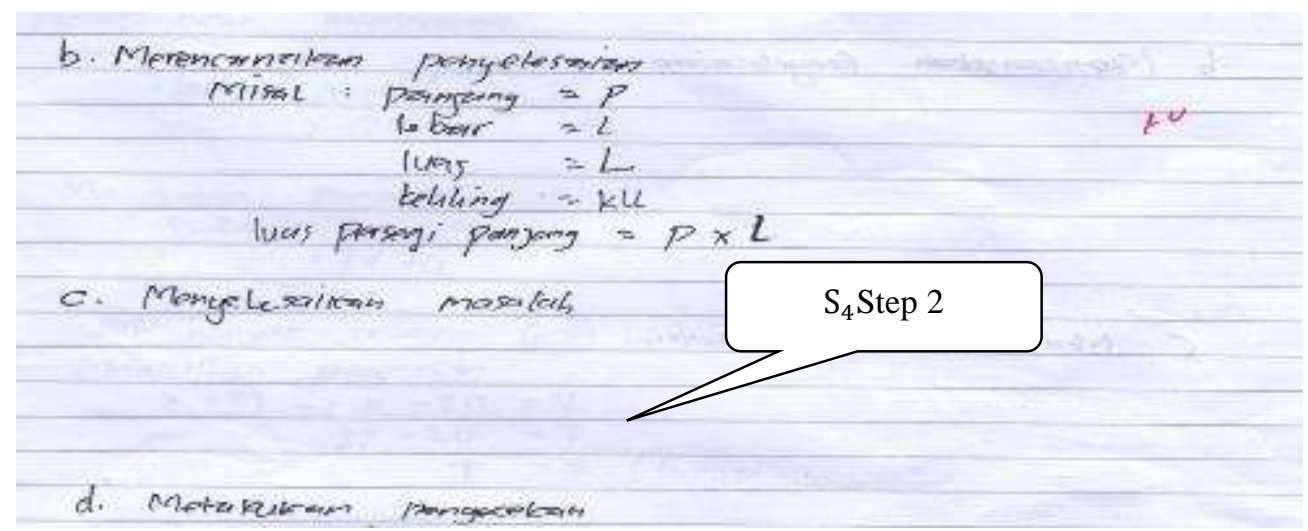

Picture 7. Student's Answer of Posttest Question 4

The fifth question "A trader managed to sell magazines $\mathrm{A}$ and $\mathrm{B}$ as many as 28 copies (sheets). The price of 1 magazine $A$ is IDR $6,000.00$ and the price of 1 magazine $B$ is IDR 9,000.00. If the sales of the two magazines are $\mathrm{Rp}$ $216,000.00$, then determine the number of magazines A and B sold"
SB also only made Polya step 2, which is understanding the problem $\left(\mathrm{S}_{5}\right.$ step 1) and planning the solution, he even made the mathematical model not complete $\left(\mathrm{S}_{5}\right.$ step 2$)$. The reason $\mathrm{SB}$ made the 2 step settlement was due to insufficient time to complete the settlement.

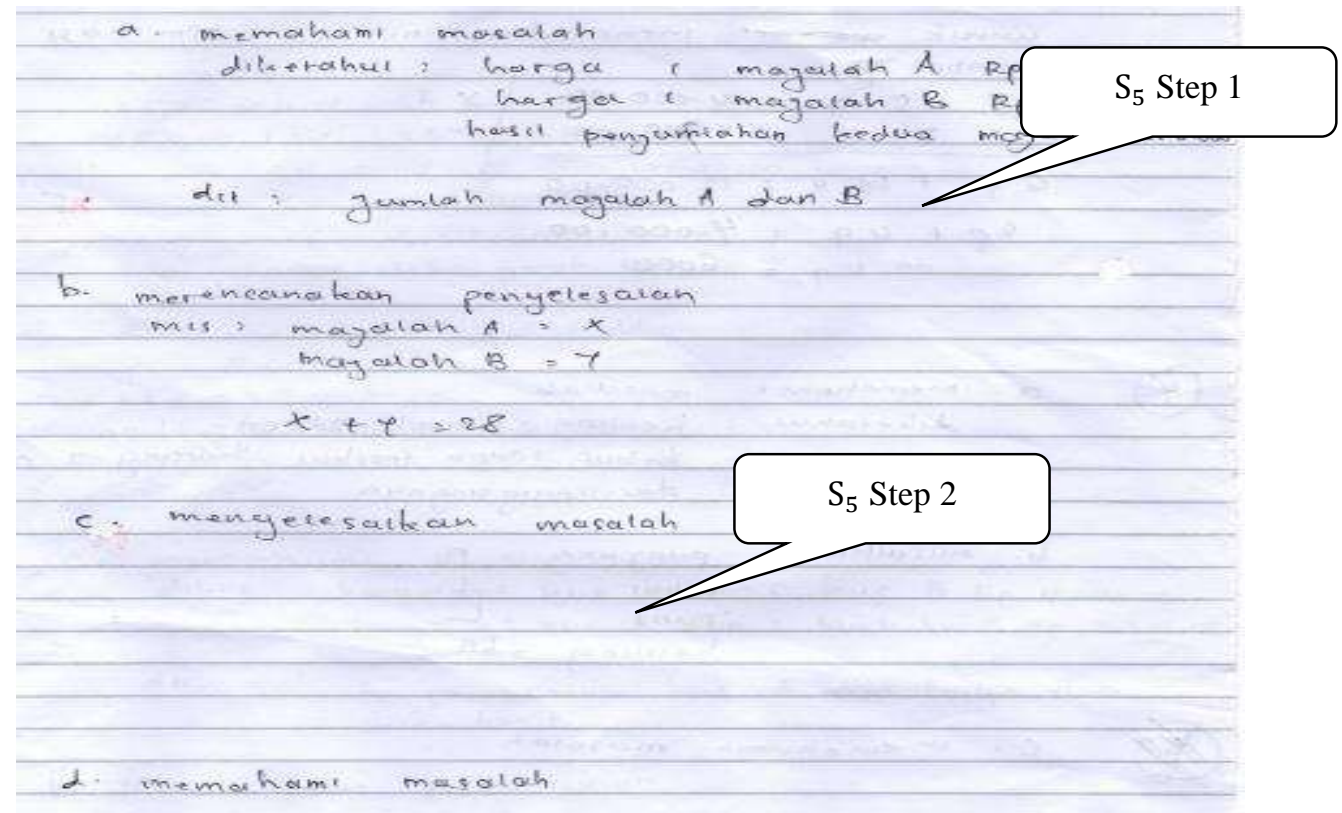

Picture 8. Student's Answer of Posttest Question 5

As for the completion of the final test questions no. 1 to 5 in the control class of students only make known, asked, and the answer was even some students were not clear in writing it like one of them, LM, while LM's answers can be seen in Figure 9 which is the solution for question no. 2. 


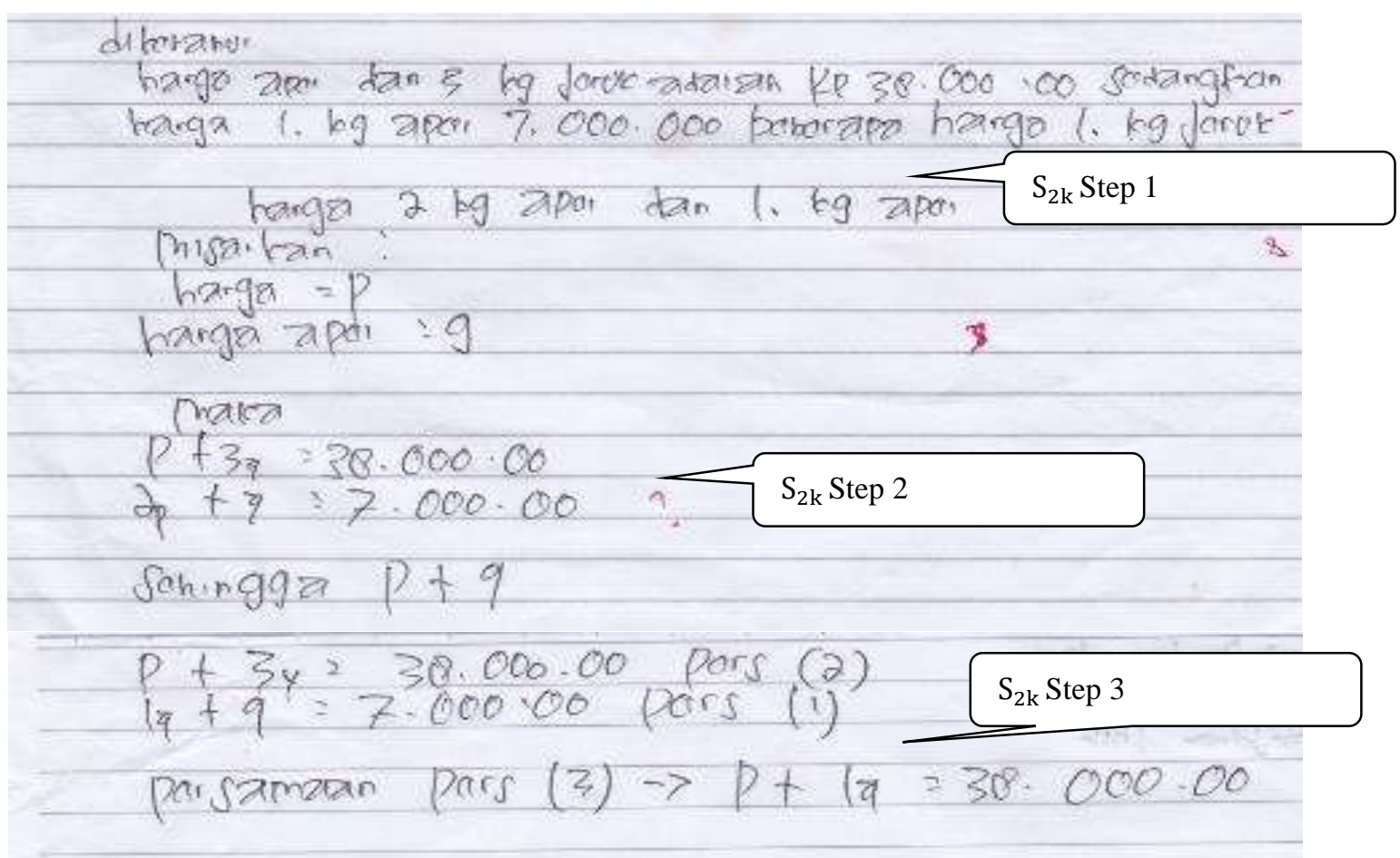

Picture 9. Student's Answer of Posttest Question 2 in Control Class

In its solution LM makes what is known in the problem without writing down what it asks $\left(S_{2 k}\right.$ step 1$), \mathrm{LM}$ in making the example and its mathematical model is also less clear $\left(S_{2 k}\right.$ step 2$)$ as well as in problem-solving $\left(S_{2 k}\right.$ step 3$)$. But here LM has tried to solve the problem.

Based on the description shows that the application of Polya's steps in problem-solving in the class VIII experiment class in SMP Negeri 3 Bayang can be said to be higher than the control class, this is because students understand about the steps that must be taken first in solving the problem.

If you pay attention to the final test in the experimental class, the number of students who reached KKM 75 was 17 completed by 10 students. The percentage of students who reached the minimum completeness criteria was $81 \%$ in the experimental class while in the control class was $48 \%$.

Improving the test results of students' problem-solving abilities can also be seen from the results of the t-test analysis with the acquisition of $t_{\text {hitung }}=$ 2.33 at the level of $\alpha=0.05$ with degrees of 62 freedom $\quad d k=n_{1}+n_{2}-2=21+21-$ $2=40$ whereas $t_{\text {tabel }}$ with a $95 \%$ confidence level is $t_{\text {tabel }}=1.68$. Thus it appears that $t_{\text {tabel }}>t_{\text {hitung }}$, meaning that $H_{0}$ is rejected and $\mathrm{H}_{1}$ is accepted. So, it can be concluded that the ability of students in problem-solving is better than without applying these steps.

\section{CLOSURE}

The results obtained are the problem-solving ability of students applying the Polya step shows the average score of the experimental class is 78.23 and the control class is 72.38 . In testing the hypothesis obtained $t_{\text {hitung }}>t_{\text {tabel }}(2,33>$ 1,68) this shows that the hypothesis is accepted. Then it can be concluded that applying the Polya step is higher than without applying the step. Suggestions that can be submitted are:

1. So that mathematics teachers in SMP / MTs, especially mathematics teachers at SMP Negeri 3 Bayang use Polya Steps in solving problems to increase students' learning abilities in story problems. 
2. Seeing the results of students' problemsolving abilities in solving story problems it is recommended that further research be carried out on other subjects.

\section{REFERENCES}

H/1974). Terjemah Tafsir Jus XI. Semarang: PT. Karya Toha Putra Semarang.

Amir, A. (2014). Pembelajaran matematika SD dengan menggunakan media manipulatif. In Forum Paedagogik (Vol. 6, No. 01).

Angraeni, Fevi. Penerapan Metode Polya untuk Meningkatkan Hasil Belajar Peserta Didik Kelas X dalam Menyelesaikan Masalah Soal Cerita Sistem Persamaan Linier Dua Variabel. Vol 2. No 4.

Arikunto, Suharsimi. (2009). Dasar-Dasar Evaluasi Pendidikan. Jakarta: Bumi Aksara.

(2013). Prosedur Penelitian Suatu Pendekatan Praktik. Jakarta: Rineka Cipta.

Al-Qur'anul Karim. (2012). Al-Qur'an dan Terjemahan. Bekasi: Cipta Bagus Segera (CBS).

Budhayanti, Clara Ika Sari. (2008). Pemecahan Masalah Matematika. Jakarta: Rektorat Jendar Pendidikan Tinggi.

Caron, F., Davy, M., \& Doucet, A. (2012). Generalized Polya urn for timevarying Dirichlet process mixtures. arXiv preprint arXiv: 1206.5254.

Chen, M. R., \& Kuba, M. (2013). On generalized Pólya urn models. Journal of Applied Probability, 50(4), 1169-1186.

D'Agostino, S. (2011). A math major, Polya, invention, and discovery. Journal of Humanistic Mathematics, 1(2), 51-55.

Daryanto. (2012). Evaluasi Pendidikan. Jakarta: Rineka Cipta.
Erman, Suherman dkk. (2003). Strategi Pembelajaran Matematika Kontemporer. Bandung: JICA UPI.

Hamalik, Oemar. (2007). Psikologi Belajar dan Mengajar. Bandung: Sinar Baru Algensindo. (2003). Pendekatan Baru Strategi Belajar Mengajar Berdasarkan CBSA. Bandung: Sinar Baru Algensindo.

Hendriana, Heris dan Utari Sumarmo. (2016). Penilaian Pembelajaran Matematika. Bandung: Refika Aditama.

Hensberry, K. K., \& Jacobbe, T. (2012). The effects of Polya's heuristic and diary writing on children's problem solving. Mathematics Education Research Journal, 24(1), 59-85.

Hui, C., Lam, S. S., \& Law, K. K. (2000). Instrumental values of organizational citizenship behavior for promotion: a field quasi-experiment. Journal of Applied Psychology, 85(5), 822.

Hurme, T. R., \& Järvelä, S. (2005). Students' activity in computersupported collaborative problem solving in mathematics. International Journal of Computers for mathematical learning, 10(1), 49-73.

Iryanti, Puji (2004). Penilaian untuk Kerja. Yogyakarta: Depdiknas.

Isnaeni. (2004). Belajar Matematika. Jakarta: Rineka Cipta.

Kemendikbud. (2013). Kerangka Dasar dan Struktur Kurikulum 2013. Jakarta: Kemendikbud.

Kilpatrick, J. (2011). Pólya on mathematical abilities. The Mathematics Educator, 21(1).

Kurniawan, Deni. (2014). Pembelajaran Terpadu Tematik (Teori, Praktik, dan Penilaian). Bandung: Penerbit Alfabet.

Kusuma, Sari. (2017). Penerapan Langkah Polya untuk Meningkatkan Hasil Belajar Peserta Didik pada Soal Cerita Sistem Persamaan Linier Dua Variabel. Vol 1. No 3. 
Lee, H. S., \& Hollebrands, K. F. (2006). Students' use of technological features while solving a mathematics problem. The Journal of Mathematical Behavior, 25(3), 252266.

Marlina, L. (2013). Penerapanlangkah Polya dalam Menyelesaikan Soal Cerita Keliling dan Luas Persegipanjang. Jurnal Elektronik Pendidikan Matematika Tadulako, 1(1).

Martono, Nanang. (2014). Metode Penelitian Kuantitatif : Analisis Isi dan Analisis Data Sekunder. Jakarta: Raja Wali Press.

Mawardi, Effendi. (2010). Istilah-Istilah dalam Praktik Mengejar dan Pembelajaran. Padang: UNP Press.

Moleong, J. Lexi. (2006). Metodologi Penelitian Kualitatif. Bandung: PT Remaja Rosdakarya.

Muliyardi. (2002). Strategi Pembelajaran Matematika. Padang: UNP Press.

Nasoetion, Noehi dkk. (2007). Evaluasi Pembelajaran Matematika. Jakarta: Universitas Terbuka.

Nelson, T. H., \& Slavit, D. (2007). Collaborative inquiry among science and mathematics teachers in the USA. Journal of in-service education, 33(1), 23-39.

Prawironegoro, Praktinyo. (1985). Evaluasi Hasil Belajar Khusus Analisis Soal Studi Matematika. Jakarta: CV Fortuna.

Polya, G. (1973). How To Solve It. New Jersey: Princeton University Press.

Pusat Bahasa Departemen Pendidikan Nasional. (2008). Kamus Bahasa Indonesia. Jakarta: Pusat Bahasa.

Rachmayani, D. (2014). Penerapan Pembelajaran Reciprocal Teaching untuk meningkatkan kemampuan komunikasi matematis dan kemandirian belajar matematika siswa. JUDIKA (Jurnal Pendidikan Unsika), 2(1).

Rahmawati, Sri Fitriatien. (2016). Jurnal Buana Matematika: Penerapan
Metode Polya pada Soal Cerita Program Linier. Surabaya: Universitas PGRI.

Ramayulis. (2004). Ilmu Pendidikan Islam. Jakarta: Kalam Mulia.

Reiser, A., \& Simmons, D. G. (2005). A quasi-experimental method. Journal of Sustainable Tourism, 13(6), 590616.

Riduwan. (2010). Metode dan Teknik Menyusun Tesis. Bandung: Alfabet.

Risnawati. (2008). Strategi Pembelajaran Matematika. Pekanbaru: Suska Press).

Sardiman. (2005). Interaksi dan Motivasi Belajar Mengajar. Jakarta: Raja Grafindo Persada.

Sari, Ratna. (2016). Jurnal Penerapan Langkah Polya untuk Meningkatkan Hasil Belajar Peserta didik pada soal Cerita Sistem Persamaan Linier Dua Variabel. Vol 4. No 1. .(2016). Pembelajaran Kalkulus Kontekstual: Suatu Modifikasi Model. Jakarta: PT Rajagrafindo Persada. . (2017). Pengembangan Modul Pembelajaran Matematika Berbasis Realistic Mathematic Education pada Materi Sistem Persamaan Linier.

Shihab, Quraish. (2002). Tafsir AlMishbah. Jakarta: Lentera Hati.

Soleha dan Rada. (2011). Ilmu Pendidikan Islam. Bandung: Shiddiq Press.

Sudjana, Nana. (2011).Penilaian Hasil Proses Belajar Mengajar.Bandung: PT Remaja Rosdakarya.

Sudjana. (2005). Metode Statistik. Bandung: Transito.

Surya, Muhammad H. (2004). Psikologi Pembelajaran dan Pengajaran. Bandung: Bani Quraisy.

Suryabrata, Sumadi. (2004). Metodologi Penelitian. Jakarta :Raja Grafindo Persada.

Susanto, Ahmad. (2012). Teori Belajar dan Pembelajaran di Sekolah Dasar. Jakarta: Kencana Prenada Media Group. 
(2014). Metodologi Penelitian. Jakarta:Raja Wali Pers.

Tarigan, D. E. (2012). Analisis kemampuan pemecahan masalah matematika berdasarkan langkah-langkah POLYA pada materi sistem persamaan linear dua variabel bagi siswa kelas VIII SMP negeri 9 Surakarta ditinjau dari kemampuan penalaran siswa (Doctoral dissertation, UNS (Sebelas Maret University)).

Tim Penulis Depdiknas. (2007). Penilaian Hasil Belajar. Jakarta: Depdiknas.

Trianto. (2010). Model Pembelajaran Terpadu. Jakarta: Bumi Aksara.

Tompira, Desi Natalia. (2016). Penerapan Model Pembelajaran Langsung dengan Menggunakan Pemecahan Masalah Polya untuk Meningkatkan Kemampuan Peserta Didik
Menyelesaikan Soal Cerita Program Linier Kelas XI SMA Negeri 4 Palu. Vol. 4. No 1.

Yuliani, Resky Putri. (2016).Penerapan Langkah-Langkah Polya untuk Meningkatkan Hasil Belajar Peserta Didik pada Materi Soal Cerita Sistem Persamaan Linier Dua Variabel di Kelas VIIII SMP Negeri 19 Palu. Jurnal Elektronik Pendidikan Matematika Tadulako Volume 04 Nomor 01.

Yusuf, Muri. (2014). Metode Penelitian (Kuantitatif, Kualitatif, dan Penelitian Gabungan). Jakarta: Prenadamedia Group).

Zainuddin. (2014). Pendidikan Agama Islam. Jakarta: Bumi Aksara.

Zakaria, Effandi. (2007). TrandPengajaran dan Pembelajaran Matematika. Kuala Lumpur: PRIN-AD, SDN, BHD. 